\begin{tabular}{c} 
Brazilian Journal \\
of Chemical \\
Engineering \\
\hline
\end{tabular}

\title{
OPTIMIZATION OF THE IMMOBILIZATION PROCESS OF $\beta$-GALATOSIDADE BY COMBINED ENTRAPMENT-CROSS-LINKING AND THE KINETICS OF LACTOSE HYDROLYSIS
}

\author{
F. F. Freitas , L. D. S. Marquez, G. P. Ribeiro, G. C. Brandão, V. L. Cardoso and E. J. Ribeiro \\ Universidade Federal de Uberlândia, Faculdade de Engenharia Química, Phone: + (55) (34) 3239-4285, Fax: + (55) (34)3239 4249, \\ Avenida João Naves de Ávila 2160, Bairro Santa Mônica, Uberlândia - MG, Brasil. \\ E-mail: *fernanda@feq.ufu.br; libiadsm@yahoo.com.br; ejribeiro@ufu.br
}

(Submitted: January 9, 2011 ; Revised: August 11, 2011 ; Accepted: August 11, 2011)

\begin{abstract}
The immobilization of Aspergillus oryzae $\beta$-galactosidase was achieved by entrapment in sodium alginate and gelatin and cross-linking with glutaraldehyde. The optimal concentrations of the aforementioned variables in the immobilization process were determined using an orthogonal central composite design with an orthogonal axial value of 1.35313 . The concentrations of alginate, gelatin and glutaraldehyde that provided the greatest enzymatic activity were $6.60 \%, 4.05 \%$ and $3.64 \%(\mathrm{w} / \mathrm{v})$, respectively. The stability of the immobilized enzyme under the optimal conditions was evaluated through daily activity assays. After 25 uses, a $20 \%$ decrease in the enzymatic activity was observed, indicating that the immobilization process could be used to produce a stable biocatalyst. This study investigates the influence of lactose and product concentrations on kinetic reaction hydrolysis. The concentration ranges for the studied variables were 10 to $56 \mathrm{~g} / \mathrm{L}$ for lactose and 0 to $11.5 \mathrm{~g} / \mathrm{L}$ for glucose and galactose. Only galactose presented a competitive inhibitory effect.

Keywords: Alginate; Aspergillus oryzae; $\beta$-galactosidase enzyme; Entrapment; Optimization, Gelatin.
\end{abstract}

\section{INTRODUCTION}

Compared to soluble forms, immobilized enzymes are more stable and can be easily separated from the reaction medium and the final product, leading to a significant decrease in enzyme consumption. To enhance the competitiveness of immobilized enzymes for technical applications, the cost of immobilization must be minimized (Tischer and Kasche, 1999; Ladero et al., 2000; Haider and Hussain, 2007; Haider and Hussain, 2009).

Lactose hydrolysis by lactase has two main biotechnological applications: the first is in the utilization of whey because both glucose and galactose have greater fermentation potential in comparison with lactose; the second is for the consumption of dairy products by lactose-intolerant persons (Ladero et al., 1998; Roy and Gupta, 2003). Lactose is a sugar that is found in milk and cheese whey, and the hydrolysis of lactose has been the subject of intense research over the last two decades because a large number of people cannot properly digest lactose due to a lack or inactivity of intestinal $\beta$-galactosidase (Ladero et al., 1998; Nakkharat and Haltrich, 2006).

The immobilization of $\beta$-galactosidase has been achieved through a variety of different methods, including physical adsorption, gel entrapment and covalent binding (Kierstan and Coughlan, 1991; Gaur et al., 2006). Moreover, a large number of immobilization processes and supports have been used (Carpio et al., 2006). The choice of support is

*To whom correspondence should be addressed 
determined by the conditions of the desired application and the method used to immobilize the enzyme (Cao, 2005).

Entrapment in alginate gel is one of the simplest methods of immobilization; however, the technique is limited by the stability and porosity of the gel, which can lead to enzyme leakage (Ates and Mehmetoglu, 1997; Parizia and Foster, 1983; Mammarella and Rubiolo, 2009). Thus, new methods of enzyme immobilization that present high enzymatic activity and good physical chemical properties are highly desirable. An approach to circumvent this leaching problem consists of cross-linking the enzyme and gelatin with glutaraldehyde, which forms an insoluble structure. Glutaraldehyde treatment also stabilizes the alginate beads and is commonly used as a crosslinking agent in combination with other composites such as gelatin (Guisan et al., 2006; Haider and Hussain, 2007; Guisan et al., 2007; Kosseva et al., 2009). The molecular microenvironment of the enzyme can be modified to increase the stability of the enzyme in the composite. In covalent immobilization methods, reagents that bind to both the enzyme and the support alter the local environment of the enzyme. Reagents that are capable of binding the support and the enzyme can be classified as small molecules (such as amino acids or other amines) or macromolecules (bovine albumin, gelatin and polyethylene glycol) (Cao, 2005). Under mild conditions, gelatin can crosslink with glutaraldehyde to form an aldimine bond; as a result, only the lysine residues of the protein are affected (Tanriseven and Dogan, 2002). Thus, the hydrolysis reaction occurs inside the beads, and the substrate penetrates into the matrix by mass transfer.

Lactase derived from Aspergillus oryzae is safe for applications in the food and pharmaceutical industry and Aspergillus oryzae has a history of safe usage (Kosseva et al. 2009). Various studies on the immobilization of $\beta$-galactosidase derived from fungi have been published (Gaur et al, 2006; Prashanth and Mulimani, 2005; Neri et al., 2009), and Aspergillus oryzae has been subjected to numerous tests (Parizia and Foster, 1983; Haider and Hussain, 2009; Zeng et al., 2009; Guidini et al., 2010; Illanes et al., 2010). Galactose has an inhibitory effect on the activity of beta-galactosidase, which is important in the design of enzymatic reactors (Ozdural et al., 2003). Beta-galactosidase from different sources has been found to exhibit competitive or mixed inhibition by galactose (Ladero et al., 1998; Haider and Hussain, 2007).

The objectives of the present study were to optimize the immobilization procedure of Aspergillus oryzae $\beta$-galactosidase in sodium alginate, gelatin and glutaraldehyde, which was employed as a reticulating agent, and to study the kinetics of lactose hydrolysis in terms of lactose and product concentrations.

\section{MATERIALS AND METHODS}

\section{Enzyme}

Aspergillus oryzae $\beta$-galactosidase (3.2.1.23) was obtained from the Sigma Chemical Co. The enzyme is available in the form of a white powder and its activity for lactose hydrolysis is 9 units per $\mathrm{mg}$. The unit of activity (U) is equal to $1 \mu \mathrm{mol}$ of lactose per minute at $30^{\circ} \mathrm{C}$ and a $\mathrm{pH}$ of 4.5 .

\section{Enzyme Activity Determination}

The catalytic activity of $\beta$-galactosidase for both forms was determined using the initial rates method. The unit of the specific activity of the free enzyme $\left(U_{F}\right)$ was defined as the grams of glucose produced per liter per minute per milligram of protein ( $\left.\mathrm{g}_{\text {glucose }} / \mathrm{L} \cdot \mathrm{min} \cdot \mathrm{mg}_{\text {protein }}\right)$. The enzyme was diluted to $1 \%(\mathrm{w} / \mathrm{v})$ in $\mathrm{pH} 4.5$ acetate buffer and contained $0.14 \mathrm{mg} / \mathrm{mL}$ of protein, which was determined using Lowry's method (Lowry et al., 1951). The immobilized enzyme activity $\left(\mathrm{U}_{\mathrm{I}}\right)$ was defined as the grams of lactose consumed per minute per $\mathrm{m}^{3}$ of immobilized biocatalyst ( $\mathrm{g}_{\text {lactose }} /\left(\min \cdot \mathrm{m}^{3} \mathrm{cat}\right)$ ). The glucose produced by the reaction was determined according to the glucose-oxidase method. The volume of biocatalyst particles was determined by measuring the displacement of the fluid volume using a pycnometer.

\section{Enzyme Immobilization}

\section{a) Experimental Design}

An orthogonal central composite design (CCD) was proposed to optimize the alginate, gelatin and glutaraldehyde concentrations in the immobilization process, which consisted of two levels and three variables. The CCD contained three replicates at the central point and 6 experiments at each axial point for a total of 17 experiments. To achieve the orthogonal CCD, an $\alpha$-value of 1.35313 (axial points) was used- The influences of alginate $\left(\mathrm{X}_{1} \%\right)$, gelatin $\left(\mathrm{X}_{2} \%\right)$ and glutaraldehyde $\left(\mathrm{X}_{3} \%\right)$ concentrations were studied in the range of 1 to $6.75 \%$ for alginate and 0 to $8.05 \%$ for gelatin and glutaraldehyde. The initial values of these variables 
were obtained through preliminary tests and based on previous results from the literature (Bódalo et al., 1991; Ates and Mehmetoglu, 1997; Becerra et al., 2001; Tanriseven and Dogan, 2002; Haider and Hussain, 2007; Haider and Hussain, 2008).

\section{b) Immobilization Procedure}

The enzyme was immobilized in technical grade sodium alginate and PA gelatin as described by Tanriseven and Dogan (2002). A suspension of sodium alginate and gelatin was diluted with water to achieve a final mass of $40 \mathrm{~g}$. The suspension was heated to $80^{\circ} \mathrm{C}$ until the alginate was completely dissolved. Subsequently, the suspension was cooled to $40^{\circ} \mathrm{C}$, and $10 \mathrm{~mL}$ of a solution of $10 \%(\mathrm{w} / \mathrm{v})$ $\beta$-galactosidase was added to achieve a final mass of $50 \mathrm{~g}$. Using a peristaltic pump, the suspension was dripped into a solution of $0.05 \mathrm{M} \mathrm{CaCl}_{2}$ and glutaraldehyde under magnetic stirring to form immobilized biocatalyst spheres with an average diameter of $4.4 \mathrm{~mm}$ that were resistant to the reaction medium conditions. The biocatalyst was stored in a solution of $0.05 \mathrm{M} \mathrm{CaCl}_{2}$ for at least 12 hours at $4^{\circ} \mathrm{C}$ before the initial activity of the immobilized enzyme was determined. In each activity assay, the biocatalyst was washed with $0.01 \mathrm{M}$ acetate buffer $(\mathrm{pH} 4.5)$. After each use, the immobilized enzyme was washed and stored in the same buffer solution. Enzyme activities that were determined immediately after the dropping and after hardening of the gel particles were essentially the same. The enzymatic activity in the supernatant after the enzyme immobilization was negligible for all immobilization assays.

\section{Influence of Lactose Concentration on the Activity of Free and Immobilized $\beta$-Galactosidase}

The relationship between $\beta$-galactosidase enzyme activity and substrate concentration (lactose) was determined experimentally using the initial reaction rates procedure in a range of substrate concentrations from 10 to $100 \mathrm{~g} / \mathrm{L}$ at $35^{\circ} \mathrm{C}$ and $\mathrm{pH} 4.5$ in an acetate buffer $\left(10^{-1} \mathrm{M}\right)$ for both forms. All of the experiments were performed in duplicate.

The hydrolysis reactions were performed in a reactor containing $50 \mathrm{~mL}$ of buffered lactose solution at the appropriate conditions of lactose concentration, $\mathrm{pH}$ and temperature. The assays were conducted in a reactor with $60 \mathrm{~mm}$ diameter with a $25 \mathrm{~mm}$ magnetic stirrer. This speed was sufficient to maintain the immobilized biocatalysts in suspension and did not cause its rupture. For the immobilized form of $\beta$-galactosidase, $15 \mathrm{~cm}^{3}$ of the immobilized enzyme beads were added to the reactor. For the soluble form of $\beta$-galactosidase, $0.5 \mathrm{~mL}$ of a solution $(1 \% \mathrm{w} / \mathrm{v})$ of the enzyme was added to the buffered solution.

\section{Influence of the Initial Concentration of Lactose,} Glucose and Galactose on the Free Enzyme Activity

A central composite design (CCD) was used to analyze the combined influence of the concentration of the reaction products (glucose and galactose) and the substrate (lactose) in the hydrolysis of lactose by $\beta$-galactosidase in the free form. The CCD contained three replicates at the center point and 6 experiments at each axial point for a total of 17 experiments. To achieve the orthogonal CCD, an $\alpha$-value of 1.35313 was used.

The concentration ranges for the studied variables were 10 to $56 \mathrm{~g} / \mathrm{L}$ for lactose and 0 to $11.5 \mathrm{~g} / \mathrm{L}$ for glucose and galactose based on preliminary studies and the works of Ladero et al. $(1998,2000)$ and Portaccio et al. (1998). Substrate inhibition was not verified in this range of lactose concentration. The experiments were performed at $35^{\circ} \mathrm{C}$ in an acetate buffer at $\mathrm{pH} 4.5$, and activities were determined using the initial reaction rates procedure. All of the experiments were carried out in duplicate.

\section{Influence of the Initial Concentration of Galactose on Free and Immobilized Enzyme Activity}

Based on the results of the previous experiments, it was concluded that glucose had no significant influence on the activity of free $\beta$-galactosidase; therefore, only the influence of the initial concentration of galactose on the enzyme activity was studied. This study was performed according to Portaccio et al. (1998) and was used to determine the enzyme activities for lactose concentrations (S) in a range of 5 to $100 \mathrm{~g} / \mathrm{L}$ in the presence of galactose concentrations (I) in a range of 0 to $10 \mathrm{~g} / \mathrm{L}$ for free and immobilized $\beta$-galactosidase as shown in Table 1.

The experiments were performed at $35^{\circ} \mathrm{C}$ with $50 \mathrm{~mL}$ of substrate solution of the desired concentrations in an acetate buffer at $\mathrm{pH} 4.5$. The study used $0.5 \mathrm{~mL}$ of $1 \%(\mathrm{w} / \mathrm{v})$ enzyme solution in an acetate buffer and different sets of immobilized biocatalysts (one for each substrate concentration) using the previously optimized immobilization conditions. All of the experiments were carried out in duplicate. The experimental results for the reaction rate were fitted to the kinetic models of competitive and non-competitive inhibition using the Statistica 7.0 software. 
Table 1: Experiments for the kinetic model study of enzyme inhibition for free and immobilized enzyme

\begin{tabular}{|c|c|c|c|c|c|}
\hline Exp. & $\begin{array}{c}\text { Lactose } \\
(\mathbf{g} / \mathbf{L})\end{array}$ & $\begin{array}{c}\text { Galactose } \\
(\mathbf{g} / \mathbf{L})\end{array}$ & $\mathbf{E x p}$. & $\begin{array}{c}\text { Lactose } \\
(\mathbf{g} / \mathbf{L})\end{array}$ & $\begin{array}{c}\text { Galactose } \\
(\mathbf{g} / \mathbf{L})\end{array}$ \\
\hline 1 & 5 & 0 & 16 & 60 & 0 \\
2 & 5 & 2.5 & 17 & 60 & 2.5 \\
3 & 5 & 5 & 18 & 60 & 5 \\
4 & 5 & 7.5 & 19 & 60 & 7.5 \\
5 & 5 & 10 & 20 & 60 & 10 \\
6 & 20 & 0 & 21 & 80 & 0 \\
7 & 20 & 2.5 & 22 & 80 & 2.5 \\
8 & 20 & 5 & 23 & 80 & 5 \\
9 & 20 & 7.5 & 24 & 80 & 7.5 \\
10 & 20 & 10 & 25 & 80 & 10 \\
11 & 40 & 0 & 26 & 100 & 0 \\
12 & 40 & 2.5 & 27 & 100 & 2.5 \\
13 & 40 & 5 & 28 & 100 & 5 \\
14 & 40 & 7.5 & 29 & 100 & 7.5 \\
15 & 40 & 10 & 30 & 100 & 10 \\
\hline
\end{tabular}

\section{RESULTS AND DISCUSSIONS}

\section{Optimization}

The central composite design permitted the identification of the optimal conditions for $\beta$-galactosidase immobilization, including the concentrations of alginate, gelatin and glutaraldehyde. After the experimental matrix was defined, the experiments were conducted and the initial activity (Y) of the immobilized enzyme was obtained as shown in Table 2.

A multiple regression analysis was conducted on the experimental data and parameters with a significance level greater than $10 \%$ were neglected. The variables that displayed a significance level lower than $10 \%$ in Student's t-test were the most relevant to the model. The results indicated that the square of the alginate concentration $\left(\mathrm{X}_{1}^{2}\right)$, the alginate concentration $\left(X_{1}\right)$, the square of the gelatin concentration $\left(X_{2}^{2}\right)$ and the square of glutaraldehyde concentration $\left(\mathrm{X}_{3}^{2}\right)$ were significant as shown in Equation (1):

$$
\begin{aligned}
Y= & 984.304+60.996 X_{1}+81.638 X_{1}^{2}- \\
& 42.505 X_{2}^{2}-45.946 X_{3}^{2}
\end{aligned}
$$

where $X_{1}, X_{2}$ and $X_{3}$ are the coded values of the concentrations of alginate, gelatin and glutaraldehyde, respectively, according to Table 1 . The coefficient of determination $\left(\mathrm{R}^{2}\right)$ of the equation was $89 \%$, indicating that the experimental data were adequately adjusted and that the aforementioned variables were related to the activity of the enzyme. Therefore, $89 \%$ of the variability of the experimental data was explained by the empirical equation. To validate the model, three experiments were performed under optimal conditions and the activities obtained by the tests were $1190.5 \mathrm{U}_{\mathrm{I}}$, 1257.6 $\mathrm{U}_{\mathrm{I}}$ and 1180.4 $\mathrm{U}_{\mathrm{I}}$. From the model (Equation (1)), the maximum activity was $1195.9 \mathrm{U}_{\mathrm{I}}$. To illustrate the effects of the variables on enzymatic activity, the response surfaces relating pairs of variables were constructed and are presented in Figures 1, 2 and 3.

Table 2: Experimental enzymatic activities in the immobilization process where $X_{1}, X_{2}$ and $X_{3}$ are the concentrations of alginate, gelatin and glutaraldehyde, respectively.

\begin{tabular}{|c|r|r|r|r|}
\hline & \multicolumn{3}{|c|}{ Codified value (Real value) } & Activity (UI) \\
\hline Exp. & $\mathbf{X}_{\mathbf{1}}$ & $\mathbf{X}_{\mathbf{2}}$ & \multicolumn{1}{|c|}{$\mathbf{X}_{\mathbf{3}}$} & $956.4 \pm 78.4$ \\
\hline 1 & $-1(1.75 \%)$ & $-1(1.05 \%)$ & $-1(1.05 \%)$ & $873.6 \pm 65.5$ \\
2 & $-1(1.75 \%)$ & $-1(1.05 \%)$ & $+1(7 \%)$ & $934.2 \pm 80.3$ \\
3 & $-1(1.75 \%)$ & $+1(7 \%)$ & $-1(1.05 \%)$ & $898.3 \pm 61.3$ \\
4 & $-1(1.75 \%)$ & $+1(7 \%)$ & $+1(7 \%)$ & $1021.8 \pm 78.7$ \\
5 & $+1(6 \%)$ & $-1(1.05 \%)$ & $-1(1.05 \%)$ & $1095 \pm 88.7$ \\
6 & $+1(6 \%)$ & $-1(1.05 \%)$ & $-1(1.05 \%)$ & $1059.8 \pm 63.7$ \\
7 & $+1(6 \%)$ & $+1(7 \%)$ & $+1(7 \%)$ & $1005.7 \pm 82.9$ \\
8 & $+1(6 \%)$ & $0(4.03 \%)$ & $0(4.03 \%)$ & $1083.6 \pm 85.6$ \\
9 & $-\alpha(1 \%)$ & $0(4.03 \%)$ & $0(4.03 \%)$ & $1181.4 \pm 100.4$ \\
10 & $+\alpha(6.75 \%)$ & $-\alpha(0 \%)$ & $0(4.03 \%)$ & $865.8 \pm 65.8$ \\
11 & $0(3.875 \%)$ & $-\alpha(8.05 \%)$ & $-\alpha(0 \%)$ & $944.9 \pm 65.2$ \\
12 & $0(3.875 \%)$ & $0(4.03 \%)$ & $+\alpha(8.05 \%)$ & $888 \pm 67.5$ \\
13 & $0(3.875 \%)$ & $0(4.03 \%)$ & $0(4.03 \%)$ & $915.8 \pm 64.1$ \\
14 & $0(3.875 \%)$ & $0(4.03 \%)$ & $0(4.03 \%)$ & $971.4 \pm 82.6$ \\
15 & $0(3.875 \%)$ & $0(4.03 \%)$ & $0(4.03 \%)$ & $993.6 \pm 79.5$ \\
16 & $0(3.875 \%)$ & $0(4.03 \%)$ & & $990.9 \pm 73.64$ \\
\hline
\end{tabular}




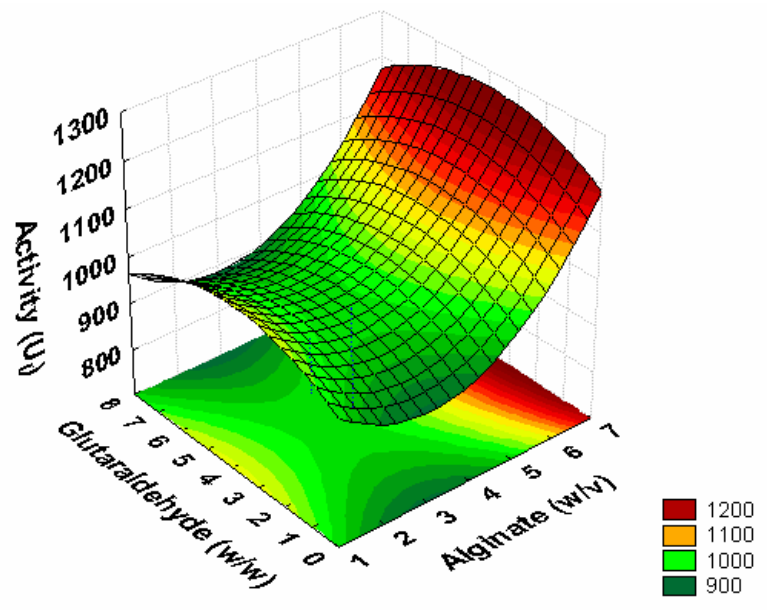

Figure 1: Response surface diagram of the enzymatic activity as a function of the alginate and gelatin concentrations

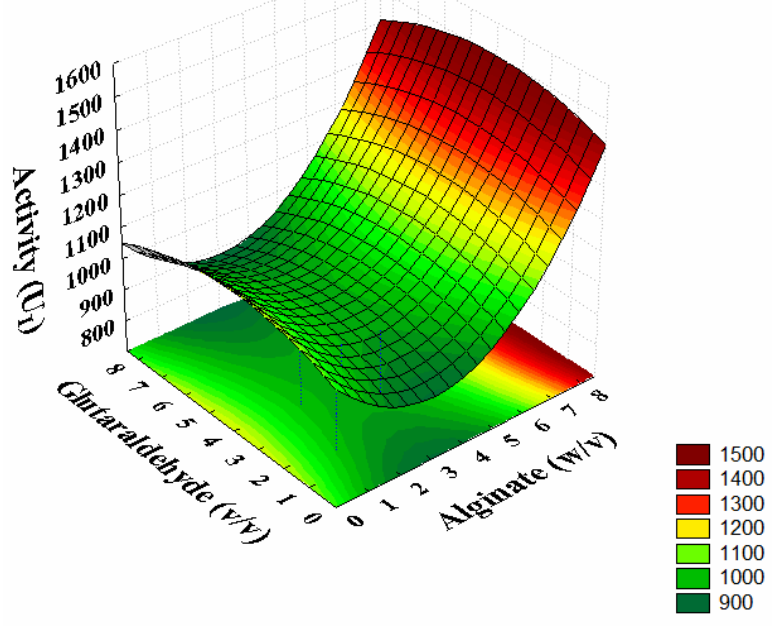

Figure 2: Response surface diagram of the enzymatic activity as a function of the alginate and glutaraldehyde concentrations

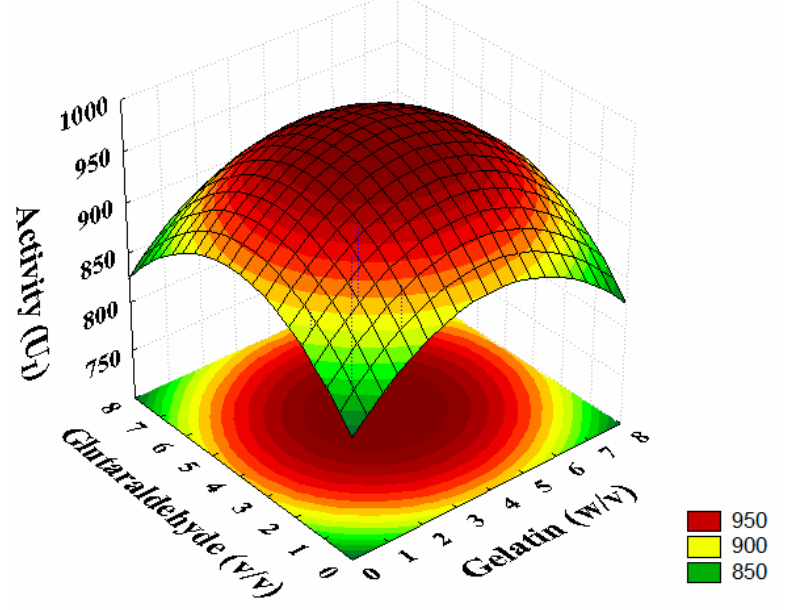

Figure 3: Response surface diagram of the enzymatic activity as a function of the glutaraldehyde and gelatin concentrations

From the complete form of Equation (1), an algorithm was implemented in Maple V (release 4) to calculate the optimal point of enzyme immobilization and to maximize enzymatic activity. The actual concentrations of the variables at the maximization point were as follows: $\mathrm{X}_{1}=6.60 \%$ alginate $(\mathrm{w} / \mathrm{v}) ; \mathrm{X}_{2}=4.05 \%$ gelatin $(\mathrm{w} / \mathrm{v})$ and $\mathrm{X}_{3}=3.64 \%$ glutaraldehyde $(\mathrm{v} / \mathrm{v})$. Under these conditions, the immobilization yield, defined as the ratio of the enzyme activity of the immobilized enzyme to the total activity of the soluble enzyme used (Emregul et al., 2006, Nogales et al., 2006), was 30\%. A further analysis of the results shown in Figures 1, 2 and 3, as well as in Table 2, revealed that the maximum enzyme activity was obtained in experiment 10 , in which the alginate concentration was $6.75 \%$ and the glutaraldehyde and gelatin concentrations were $4.03 \%$. Note that these values are very close to those obtained at the optimal point of maximum activity.

To study the stability of the immobilized enzyme under the optimized conditions, enzymatic activity was measured daily and the activity of the immobilized biocatalyst under optimized conditions decreased by only $20 \%$ after 25 uses. In addition, the half-life of the immobilized enzyme was 12.8 hours at $53^{\circ} \mathrm{C}$, with a activation energy for the thermal deactivation process of $72.03 \mathrm{kcal} / \mathrm{mol}$. These results confirmed that the optimized conditions led to high enzyme retention in the support. Therefore, compared to similar processes reported in the literature, the proposed process of 
immobilization produced a sufficient and stable biocatalyst at a low cost.

\section{Influence of Lactose Concentration on the} Activity of Free and Immobilized $\beta$-Galactosidase

The experimental reaction rates were fitted to the Michaelis-Menten model in a lactose concentration range of 10 to $100 \mathrm{~g} / \mathrm{L}$ for free and immobilized enzymes. Through a non-linear regression, which was performed using Statistica 7.0 using the numerical method of Levenberg-Marquardt, the values of the parameters with significant values at $5 \%$ (p-value $<0.05$ ) were estimated. The $\mathrm{V}_{\mathrm{m}}$ and $\mathrm{K}_{\mathrm{m}}$ values were $2.56 \pm 0.3 \mathrm{U}_{\mathrm{F}}$ and $17.83 \pm 0.9 \mathrm{~g} / \mathrm{L}$ (52.13 $\mathrm{mM})$, respectively, $\left(\mathrm{R}^{2}=96.16 \%\right)$ for the free enzyme. For the immobilized form, these parameters were $1032.07 \pm 51.6 \mathrm{U}_{\mathrm{I}}$ and $20.63 \pm 1.0 \mathrm{~g} / \mathrm{L}(60.3 \mathrm{mM})$, respectively $\left(\mathrm{R}^{2}=90 \%\right)$. Similar values of the $\mathrm{K}_{\mathrm{m}}$ parameter for both enzyme forms were observed, showing that the free and immobilized enzyme forms presented similar affinities for the substrate.

\section{Influence of the Initial Concentrations of Lactose, Glucose and Galactose on Free Enzyme Activity}

After defining the central composite design (CCD) matrix, the experiments were conducted and the initial activities (Y) of the free enzyme were determined as shown in Table 3.

A multiple regression analysis was conducted on the experimental data and parameters with a significance level greater than $10 \%$ were neglected. These results are presented in Equation (2) $\left(\mathrm{R}^{2}=96.9 \%\right)$.

$$
\begin{aligned}
Y= & 1.137+0.417 \mathrm{X}_{4}+0.127 \mathrm{X}_{4}^{2}+0.168 \mathrm{X}_{5}- \\
& 0.322 \mathrm{X}_{6}+0.141 \mathrm{X}_{6}^{2}-0.144 \mathrm{X}_{4} \mathrm{X}_{5}+ \\
& 0.126 \mathrm{X}_{4} \mathrm{X}_{6}-0.162 \mathrm{X}_{5} \mathrm{X}_{6}
\end{aligned}
$$

where $\mathrm{X}_{4}, \mathrm{X}_{5}$ and $\mathrm{X}_{6}$ are the coded concentrations of lactose, glucose and galactose, respectively. Figures 4, 5 and 6 represent the respective response surfaces.

Figure 4 shows that the region of maximum activity was found for higher levels of lactose concentration, which was expected because the maximum concentration of lactose was approximately $50 \mathrm{~g} / \mathrm{L}$, which is a value that does not reach the range of substrate inhibition. Under these conditions, enzyme activity was independent of glucose concentration; therefore, glucose did not affect the maximization of enzymatic activity response, only the lactose concentration. Figure 5 illustrates the influence of the galactose concentration on enzymatic activity. A range of highest enzyme activity is observed for low levels of galactose and lower activities are found at higher galactose concentrations. Figure 6 shows the inhibitory effect of galactose, and the highest activities occurred with higher concentrations of glucose and low concentrations of galactose. Figures 4 and 6 show a clear increase in activity with glucose concentration, suggesting that glucose may be acting as an activator of enzyme activity. Therefore, only galactose had an inhibitory effect on the hydrolysis of lactose by $\beta$-galactosidase in its soluble form.

Table 3: Experimental enzymatic activities as a function of the initial concentrations of lactose, glucose and galactose for the free enzyme.

\begin{tabular}{|c|c|c|c|c|}
\hline & \multicolumn{3}{|c|}{ Real value (Codified value ) } & \multirow{2}{*}{ Activity (UF) } \\
\hline Exp. & $\begin{array}{c}\mathbf{X}_{\mathbf{4}} \\
\text { Lactose (g/L) }\end{array}$ & $\begin{array}{c}\mathbf{X}_{\mathbf{5}} \\
\text { Glucose(g/L) }\end{array}$ & $\begin{array}{c}\mathbf{X}_{\mathbf{6}} \\
\text { Galactose (g/L) }\end{array}$ & $0.918 \pm 0.036$ \\
\hline 1 & $16(-1)$ & $1.5(-1)$ & $1.5(-1)$ & $0.283 \pm 0.012$ \\
2 & $16(-1)$ & $1.5(-1)$ & $10(+1)$ & $2.001 \pm 0.076$ \\
3 & $16(-1)$ & $10(+1)$ & $1.5(-1)$ & $0.597 \pm 0.033$ \\
4 & $16(-1)$ & $10(+1)$ & $10(+1)$ & $1.919 \pm 0.089$ \\
5 & $50(+1)$ & $1.5(-1)$ & $1.5(-1)$ & $1.668 \pm 0.079$ \\
6 & $50(+1)$ & $1.5(-1)$ & $10(+1)$ & $2.305 \pm 0.11$ \\
7 & $50(+1)$ & $10(+1)$ & $1.5(-1)$ & $1.525 \pm 0.05$ \\
8 & $50(+1)$ & $10(+1)$ & $5.75(0)$ & $0.914 \pm 0.051$ \\
9 & $10(-\alpha)$ & $5.75(0)$ & $5.75(0)$ & $1.838 \pm 0.11$ \\
10 & $56(+\alpha)$ & $5.75(0)$ & $5.75(0)$ & $1.177 \pm 0.052$ \\
11 & $33(0)$ & $0(-\alpha)$ & $5.75(0)$ & $1.413 \pm 0.066$ \\
12 & $33(0)$ & $11.5(+\alpha)$ & $0(-\alpha)$ & $1.828 \pm 0.071$ \\
13 & $33(0)$ & $5.75(0)$ & $5.5(+\alpha)$ & $0.975 \pm 0.054$ \\
14 & $33(0)$ & $5.75(0)$ & $5.75(0)$ & $1.064 \pm 0.06$ \\
15 & $33(0)$ & $5.75(0)$ & $5.75(0)$ & $0.975 \pm 0.05$ \\
16 & $33(0)$ & $5.75(0)$ & & $1.053 \pm 0.05$ \\
\hline
\end{tabular}




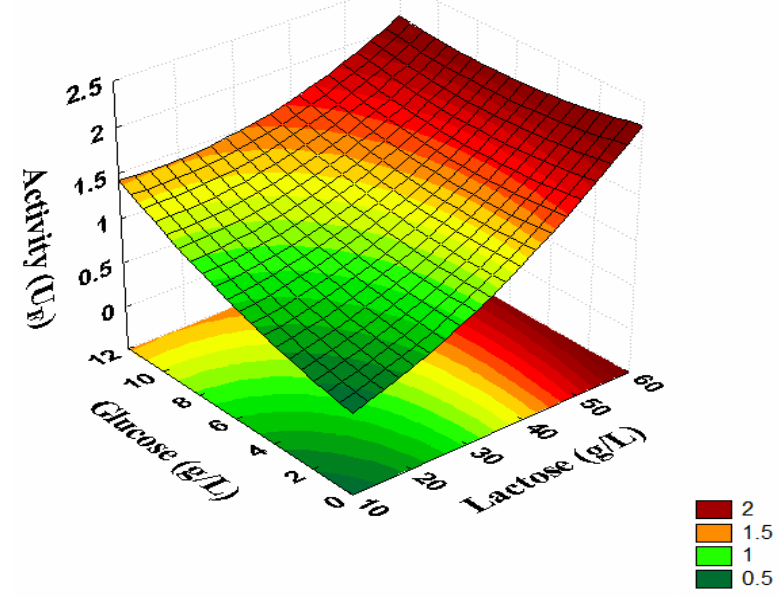

Figure 4: Response surface for the activity as a function of the variables lactose and glucose concentrations.

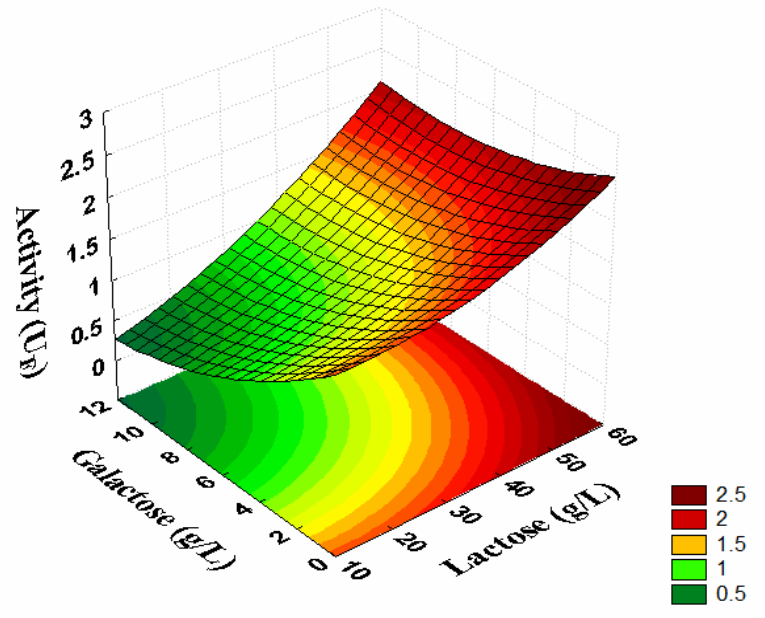

Figure 5: Response surface for the activity as a function of the variables lactose and galactose concentrations.

Hatzinikolaou et al. (2005) used $\beta$-galactosidase from Aspergillus niger to hydrolyze lactose in acid cheese whey permeate and found that only galactose acted as a competitive inhibitor. Jurado et al. (2002; 2004) also concluded that galactose acted as a competitive inhibitor for Kluyveromyces fragilis $\beta$-galactosidase during the hydrolysis of lactose. According to Ladero et al. (2000), several authors also have observed competitive inhibition by galactose using different sources of $\beta$-galactosidase.

\section{Influence of the Initial Concentration of Galactose on Free and Immobilized Enzyme Activity}

An analysis of the results of the influence of the reaction products showed that galactose has a

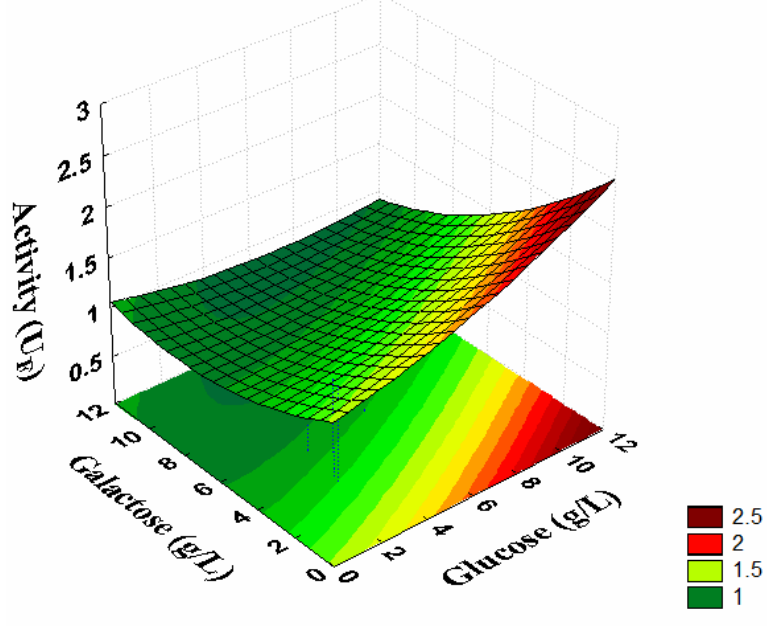

Figure 6: Response surface for the activity as a function of the variables glucose and galactose concentrations.

significant inhibitory effect on $\beta$-galactosidase activity. The experimental results for the reaction rate of lactose hydrolysis by free and immobilized $\beta$-galactosidase in the presence of galactose were fitted by non-linear regression to the kinetic models of competitive and non-competitive inhibition using Statistica 7.0 through the Levenberg-Marquardt method. The choice of inhibition model that was fitted to the experimental results was based on the physical meaning of its parameters, which were a significance level of less than $10 \%$ by Student's t-test, a higher coefficient of determination $\left(R^{2}\right)$ and the lowest sum of squares deviations. Table 4 presents the fitted parameters with the corresponding Student's t-test, the coefficients of determination and the sum of squares deviations for the effect of inhibition caused by galactose. 
Table 4: Kinetic parameters in the presence of galactose as an inhibitor

\begin{tabular}{|l|l|r|r|r|r|c|}
\hline $\begin{array}{l}\text { Inhibition model } \\
\text { I=Galactose }\end{array}$ & $\begin{array}{r}\mathbf{V m} \\
\left(\mathbf{U}^{*}\right)\end{array}$ & $\begin{array}{c}\mathbf{K m} \\
(\mathbf{m M})\end{array}$ & $\mathbf{K i}(\mathbf{m M})$ & $\sum\left(\mathbf{V}-\mathbf{V}_{\mathbf{M}}\right)^{\mathbf{2}}$ & $\mathbf{R}^{\mathbf{2}}$ \\
\hline Competitive (free) & Parameters & 2.4 & 51.49 & 5.64 & 0.255 & $96.35 \%$ \\
& p-level & 0 & 0.0001 & 0 & & \\
Noncompetitive (free) & Parameters & 3.14 & 100.4 & 23.27 & 0.200 & $97.34 \%$ \\
Competitive & p-level & 0 & 0 & 0 & & \\
(immobilized) & Parameters & 633.6 & 48.8 & 53.33 & 97917.9 & $82.7 \%$ \\
Noncompetitive & p-level & 0 & 0.001 & 0.07 & & \\
(immobilized) & Parameters & 821.0 & 102.3 & 290.5 & 80312.8 & $87.4 \%$ \\
\hline
\end{tabular}

$\mathrm{U}^{*}$ : UF for free and UI for immobilized enzyme

For the free enzyme, the non-competitive inhibition model had the highest $\mathrm{R}^{2}$ value and the lowest sum of squares deviations and all of the parameters were statistically significant. However, the values of the parameters $\mathrm{V}_{\mathrm{m}}$ and $\mathrm{K}_{\mathrm{m}}$ were very different when compared with the values obtained by analyzing the influence of the concentration of lactose in the absence of inhibitors, which was then adjusted by the Michaelis-Menten model. In the noncompetitive inhibition model, the $\mathrm{V}_{\mathrm{m}}$ value does not reach that obtained by the Michaelis-Menten model without an inhibitor; therefore, the value of $\mathrm{V}_{\mathrm{m}}$ of $3.14 \mathrm{U}_{\mathrm{F}}$ was considered to be very high when compared with the value of $2.56 \mathrm{U}_{\mathrm{F}}$ that was previously obtained. In the competitive inhibition the $\mathrm{V}_{\mathrm{m}}$ value can achieve the value of $\mathrm{V}_{\mathrm{m}}$ of the Michaelis-Menten model, which was actually observed. Based on this analysis, the model that best fitted the data was the competitive inhibition by galactose, which showed $\mathrm{K}_{\mathrm{m}}$ and $\mathrm{K}_{\mathrm{i}}$ values of 51.49 and $5.64 \mathrm{mM}$, respectively. Hatzinikolaou et al. (2005) found $K_{m}$ and $K_{i}$ values of 31.8 and $6.56 \mathrm{mM}$, respectively, for the model of competitive inhibition by galactose for $\beta$-galactosidase from Aspergillus niger. Mateo et al. (2004), using $\beta$-galactosidase from Kluyveromyces lactis, found competitive inhibition by galactose and obtained $\mathrm{K}_{\mathrm{m}}$ and $\mathrm{K}_{\mathrm{i}}$ values of 3.6 and $758 \mathrm{mM}$, respectively.

For the enzyme in its immobilized form, the noncompetitive inhibition model showed the highest $\mathrm{R}^{2}$ and lowest sum of squares deviations, but the parameter $\mathrm{K}_{\mathrm{i}}$ showed a p-value greater than $10 \%$, which made the model statistically invalid. Therefore, the best-fit model was competitive inhibition by galactose, confirming the same result obtained for the enzyme in its free form. The $\mathrm{K}_{\mathrm{m}}$ and $\mathrm{K}_{\mathrm{i}}$ values were 48.8 and $53.33 \mathrm{mM}$, respectively, for the competitive inhibition model. This same model for inhibition by galactose is found in the work of Portaccio et al. (1998), in which the enzyme $\beta$-galactosidase from Aspergillus oryzae was immobilized on chitosan beads and nylon membrane. This study showed that the value of $\mathrm{K}_{\mathrm{i}}$ for the immobilized form was much higher than for the free enzyme, indicating that there was a reduction of the inhibition by galactose in immobilized biocatalysts. It has been recently shown that immobilization can reduce enzyme inhibition (Pessela et al. 2007, Mateo et al. 2007).

\section{CONCLUSIONS}

The results of this study demonstrated that the optimal conditions for the immobilization of $\beta$-galactosidase were $6.60 \%$ alginate $(\mathrm{w} / \mathrm{v}), 4.05 \%$ gelatin $(\mathrm{w} / \mathrm{v})$ and $3.64 \%$ glutaraldehyde $(\mathrm{v} / \mathrm{v})$. The immobilized enzyme obtained under the optimized conditions maintained $80 \%$ of its initial activity after 25 uses. For the studied lactose concentrations, which ranged from 10 to $100 \mathrm{~g} / \mathrm{L}$, there was no substrate inhibition for the enzyme in its immobilized form. The Michaelis-Menten kinetic model with competitive inhibition by galactose was the best-fit model for the experimental results of the reaction rate for the hydrolysis of lactose by free and immobilized $\beta$-galactosidase. The values of $\mathrm{K}_{\mathrm{m}}$ and $\mathrm{K}_{\mathrm{i}}$ for the free enzyme were 51.49 and $5.64 \mathrm{mM}$, respectively, and 48.83 and $53.33 \mathrm{mM}$, respectively, for the immobilized enzyme. Glucose did not significantly influence $\beta$-galactosidase activity.

\section{REFERENCES}

Ates, S. and Mehmetoglu, Ü., A new method for immobilization of $\beta$-galactosidase and its utilization in a plug flow reactor. Process Biochemistry, 32, (5), 433-436 (1997).

Becerra, M., Baroli, B., Fadda, A. M., Blanco Méndez, J. and González Siso, M. I., Lactose bioconversion by calcium-alginate immobilization of Kluyveromyces 
lactis cells. Enzyme and Microbial Technology, 29, 506- 512 (2001).

Bódalo, A., Gómez, E., Gómez, J. L., Bastida. J., Máximo. M. F., Díaz, F. A., Comparison of different methods of $\beta$-galactosidase immobilization, Process Biochemistry, 26, 349-353 (1991).

Cao, L., Immobilised enzymes: Science or Art? Current Opinion in Chemical Biology, 9, 217-226 (2005).

Carpio, C., González, P., Ruales, J. and BatistaViera, F., Bone-bound enzymes for food industry application. Food Chemistry, 68, 403-409 (2006).

Emregul, E., Sungur, S., Akbulut, U., Polyacrylamidegelatine carrier system used for invertase immobilization. Food Chemistry, 97, 591-597 (2006).

Gaur, R., Pant, H., Jain, R. and Khare, S. K., Galactooligosaccharide by immobilized Aspergillus oryzae $\beta$-galactosidase. Food Chemistry, 97, 426-430 (2006).

Guidini, C. Z. , Fisher, J., Santana, L. N. S., Cardoso, V. L., Ribeiro, E. J., Immobilization of Aspergillus oryzae $\beta$-galactosidase in ion exchange resins by combined ionic-binding method and crosslinking. Biochemical Engineering Journal (2010).

Guisán, J. M., Betancor, L., López-Gallego, F., Hidalgo, A., Alonso-Morales, N., DellamoraOrtiz, G., Mateo, C., Fernández-Lafuente, R., Different mechanism of protein immobilization on glutaraldehyde activated supports: Effect of support activation and immobilization conditions. Enzyme and Microbial Technology, 39, 877-882 (2006).

Guisan, J. M., Fernandez-Lafuente, R., Mateo, C., Palomo, J. M., Fernandez-Lorente, G., Improvement of enzyme activity, stability and selectivity via immobilization techniques. Enzyme and Microbial Technology, 40, 1451-1463 (2007).

Haider, T. and Hussain, Q., Calcium alginate entrapped preparations of Aspergillus oryzae $\beta$ galactosidase: Its stability and applications in the hydrolysis of lactose. International Journal of Biological Macromolecules, 41, 72-80 (2007).

Haider, T. and Hussain, Q., Immobilization of galactosidase from Aspergillus oryzae via immunoaffinity support. Biochemical Engineering Journal, 43, 307-314 (2009).

Hatzinikolaou, D. G., Katsifas, E., Mamma, D., Karagouni, A. D., Christakopoulos, P., Kekos, D., Modeling of the simultaneous hydrolysisultrafiltration whey permeate by a thermostable $\beta$-galactosidase from Aspergillus oryzae. Biochemical Engineering Journal, v. 24, pp.161172 (2005).
Illanes, A., Martín Huerta, L., Vera, C., Guerrero, C., Wilson, L., Synthesis of galacto-oligosaccharides at very high lactose concentrations with immobilized beta-galactosidases from Aspergillus oryzae. Process Biochemistry, 46, 245-252 (2011).

Jurado, E., Camacho, F., Luzón, G., Vicaria, J. M., A new kinetic model proposed for enzymatic hydrolysis of lactose by $\beta$-galactosidase from Kluyromyces fragilis. Enzyme and Microbial Technology, v. 31, pp. 300-309 (2002).

Jurado, E., Camacho, F., Luzón, G., Vicaria, J. M., Kinetic model of activity for proposed for $\beta$-galactosidases: influence of $\mathrm{pH}$, ionic concentration and temperature. Enzyme and Microbial Technology, v. 34, pp. 33-40 (2004).

Kierstan, M. P. J. and Coughlan, M. P., Immobilization of proteins by noncovalent procedures: principles and applications, In R. F. Taylor, Protein Immobilization, Fundamentals and Applications, 13-1 (1991).

Kosseva, M. R., Panesar, P. S., Kaur, G., Kennedy, J. F., Use of immobilised biocatalysts in the processing of cheese whey. International Journal of Biological Macromolecules, 45 437-447 (2009).

Ladero, M., Santos, A., García-Ocha, F., Kinetic modeling of lactose hydrolysis by a $\beta$ galactosidase from Kluyveromyces fragilis. Enzyme and Microbiology Technology, 22, 558567 (1998).

Ladero, M., Santos, A., García-Ochoa, F., Kinetic modeling of lactose hydrolysis with an immobilized $\beta$-galactosidase from Kluyveromyces fragilis. Enzyme and Microbiology Technology, v. 27, pp. 583-592 (2000).

Mammarella, E. and Rubiolo, A. C., Effect of biocatalyst swelling on the operation of packedbed immobilized enzyme bioreactor. Process Biochemistry, 44, 183-190 (2009).

Mateo, C., Monti, R., Pessela, B. C. C., Fuentes, M., Torres, R., Guisán, J. M., Lafuente, R. F., Immobilization of lactase from Kluyveromyces lactis greatly reduces the inhibition promoted by glucose. Full hydrolysis of lactose in Milk, Biotechnol. Prog., v. 20, pp. 1259-1262 (2004).

Nakkharat, P. and Haltrich, D., Lactose hydrolysis and formation of galactooligosaccharides by a novel immobilized $\beta$-galactosidase from the thermophilic fungus Talaromyces thermophilus. Applied Biochemistry and Biotechnology, 129132, 215-225 (2006).

Neri, D. F. M., Balcão, V. M., Costa R. S., Rocha, I. C. A. P, Ferreira, E. M. F. C., Torres, D. P. M., 
Rodrigues, L. R. M., Carvalho, Jr., L. B., Teixeira, J. A., Galacto-oligosaccharides production during lactose hydrolysis by free Aspergillus oryzae $\beta$-galactosidase and immobilized on magnetic polysiloxane-polyvinyl alcohol Food Chemistry 115 92-99 (2009).

Nogales, J. M. R., López, A. D., A novel approach to develop $\beta$-galactosidase entrapped in liposomes in order to prevent an immediate hydrolysis of lactose in milk. International Dairy Journal, 16, 354-360 (2006).

Ozdural, A. R., Tanyolaç, D., Boyaci, I. H., Mutlu, M., Webb, C., Determination of apparent kinetic parameters for competitive product inhibition in packed-bed immobilized enzyme reactors. Biochemical Engineering Journal, v. 14, pp. 27-36 (2003).

Parizia, M. W. and Foster, F. M., Determining the Safety of enzymes used in food processing. Journal of Food Protection, 46, 5, 453-468 (1983).

Portaccio, M., Stellato, S., Rossi, S., Bencivenga, U., Eldin, M. S. S., Gaeta, F. S., Mita, D. G., Galactose competitive inhibition of $\beta$-galactosidase
(Aspergillus oryzae) immobilized on chitosan and nylon supports. Enzyme Microbial Technology. v. 23, pp.101-106 (1998).

Prashanth, S. J. and Mulimani, V. H., Soymilk oligosaccharide hydrolysis by Aspergillus oryzae $\alpha$-galactosidase immobilized in calcium alginate. Process Biochemistry, 40, 1199-1205 (2005).

Roy, I. and Gupta, M. N., Lactose hydrolysis by Lactosym TM immobilized on cellulose beads in batch and fluidized bed modes. Process Biochemistry, v. 39, pp. 325-332 (2003).

Tanriseven, A. S. and Dogan, E., A novel method for the immobilization of de $\beta$-galactosidase. Process Biochemistry, 38, 27-30 (2002).

Tischer, W. and Kasche, V., Immobilized enzymes: crystals or carriers? Reviews. Tibtech., 17, 326-335 (1999).

Zeng, X., Pan, C., Hu, B., Li, W., Sun, Y., Ye, H., Novel and efficient method for immobilization and stabilization of beta-d-galactosidase by covalent attachment onto magnetic $\mathrm{Fe} 3 \mathrm{O} 4$ chitosan nanoparticles. Journal of Molecular Catalysis B: Enzymatic 61 208-215 (2009). 